\title{
PENGARUH TEKNIK PENGELOMPOKAN (CLUSTERING) TERHADAP KEMAMPUAN MENULIS TEKS BERITA OLEH MAHASISWA SEMESTER III PROGRAM STUDI PENDIDIKAN BAHASA DAN SASTRA INDONESIA TAHUN PEMBELAJARAN 2017/2018
}

\author{
Sri Listiana Izar (srilistiana@umsu.ac.id) \\ Oktavia Lestari Pasaribu (oktavialestari1990@yahoo.com) \\ Universitas Muhammadiyah Sumatera Utara
}

\begin{abstract}
ABTRAK
Ada empat keterampilan berbahasa yang tidak dapat dipisahkan antara satu dengan lain, hal ini didukung oleh Tarigan (1986:1) bahwa keterampilan berbahasa memiliki empat komponen yaitu keterampilan menyimak, keterampilan berbicara, keterampilan menulis, dan keterampilan membaca.Dengan menulis, mahasiswa dapat mengungkapkan dan mengekspresikan gagasan atau pendapat, pemikiran, dan perasaan yang dimiliki. Selain itu, menulis juga dapat mengembangkan daya pikir dan kreativitas mahasiswa.Data dalam penelitian ini diperoleh dengan mengadakan tes. Tes dilakukan dengan mengunakan soal-soal yang dibuat dan disusun oleh peneliti. Tes dilakukan sebanyak dua kali yaitu pada siklus I dan siklus II. Skor penilaian berdasarkan aspek-aspek yangsudah ditentukan. Dalam melakukan tes ini, diperlukan instrumen yang berupa pedoman atau kriteria penilaian. Penilaian tersebut menunjukan pencapaian aspek pokok yang dijadikan kreteria penilaian, yaitu : (1) kelengkapan unsur berita (mengandung ADIKSIMBA); (2) keruntutan pemaparan (isi urut dan jelas sehingga mudah dipahami); (3)penggunaan kalimat (singkat dan jelas); (4) penggunaan kosa kata (tepat); (5) kemanarikan judul; dan (6)ketepatan penggunaan ejaan dalam berita.Untuk menilai kemampuan mahasiswa dalam menulis teks berita, data memegang peranan penting. Untuk memperoleh data tersebut banyak cara yangditempuh, ada yang mengunakan tes, angket, wawancara, dan sebagainya sesuai dengan data yang dibutuhkan.
\end{abstract}

Kata Kunci: Teknik Pengelompokan, menulis teks berita

\section{PENDAHULUAN}

Kemampuan menulis adalah salah satu kemampuan berbahasa yang dianggap paling komplek karna melibatkan berbagai kemampuan kognitif dan linguistik (Marhaeni dalam Pharyuna 2012:46). Jika berbicara soal kemampuan, maka menulis sesuatu yang bisa dipelajari dan dikuasai.

Ada hal yang menjadi sifat dasar dari sebuah kemampuan. Pertama, kemampuan tidak muncul secara langsung, tetapi melalui proses atau tahapan yang sistematis. Jika tahapan itu tidak dilalui secara berurutan, maka akan memunculkan resiko pada orang yang belajar menguasai kemampuan tersebut. Kedua, kemampuan dapat melalui sebuah latihan yang berulang-ulang yang tidak jarang menghasilkan kegagalan. Selama orang bisa melewati ketidak berhasilan dengan sabar, maka kemampuan lama kelamaan akan dikuasai.

Kegiatan menulis memerlukan sejumlah potensi pendukung yang untuk mencapainya diperlukan kesungguhan, kemauan keras, dan harus belajar dan berlatih dengan sungguh-sungguh dan terus-menerus dalam waktu yang cukup lama. Dengan demikian, wajar bila dikatakan bahwa menciptakan iklim budaya tulis akan mendorong seseorang menjadilebih aktif, lebih kreatif dan lebih cerdas. Hal ini bisa terjadi karena untuk menyiapkan sebuah tulisan, sejumlah komponen harus dikuasai, mulai dari hal-hal sederhana,seperti memilih kata, merangkai kalimat, sampai-sampai hal-hal yang agak rumit, yaitu merangkai Paragraf. 
Ada sebuah teknik yang diyakini oleh peneliti dapat membantu mahasiswa agar berani menuangkan gagasan idenya untuk menulis teks berita yaitu teknik pengelompokan (clustering) atau pengelompokan yang efektif dan menyenangkan. Teknik ini melibatkan aktivitas otak kanan mahasiswa, kembali ke "cara bercerita" apa adanya saat masih anak-anak. Teknik ini juga membuat mahasiswa bekerja secara alamiah dengan gagasan-gagasan tanpa menyuntingnya sama sekali. Dengan pengelompokan ini juga akan menempatkan kata dalam tingkatan yang sama dengan gagasan-gagasan lainnya. Hal ini seperti dinyatakan oleh Porter (2013:182),

“ Teknik ini sangat ampuh karena ia membuat Anda bekerja secara alamiah dengan gagasan-gagasan tanpa menyuntingnya sama sekali. Jika Anda seperti kebanyakan orang, banyak gagasan Anda tak akan pernah tertuang di atas kertas karena yakin bahwa gagasan-gagasan itu tak cukup baik atau tidak berhubungan dengan topik yang sedang Anda kerjakan.”

Berdasarkan uraian di atas, peneliti tertarik untuk menggunakan teknik pengelompokan (clustering) dan melihat sejauh mana pengaruhnya terhadap kemampuan menulis berita, sehingga peneliti menentukan judul "Pengaruh teknik pengelompokan (clustering) terhadap kemampuan menulis teks berita oleh mahasiswa semester III program studi pendidikan bahasa dan sastra Indonesia FKIP UMSU tahun pembelajaran 2017-2018.”

Berdasarkan latar belakang, maka peneliti merumuskan masalah penelitian ini sebagai berikut:

1. Bagaimana proses pembelajaran menulis teks berita oleh mahasiswa semester III program studi pendidikan bahasa dan sastra Indonesia FKIP UMSU tahun pembelajaran 2017-2018?

2. Bagaimanakah perubahan prilaku mahasiswa semester III program studi pendidikan bahasa dan sastra Indonesia selama mengikuti pembelajaraan dengan teknik pengelompokan (Clustering)?

3. Bagaimana peningkatan keterampilan menulis teks berita mahasiswa semester III program studi pendidikan bahasa dan sastra Indonesia FKIP UMSU tahun pembelajaran 2017-2018 setelah pembelajaran menggunakan teknik pengelompokan (Clustering)?

Tujuan penelitian ini adalah:

1. Untuk mengetahui kemampuan menulis teks berita dengan menggunakan teknik pengelompokan (clustering) oleh mahasiswa semester III program studi pendidikan bahasa dan sastra Indonesia FKIP UMSU tahun pembelajaran 2017-2018?

2. Untuk mengetahui kemampuan menulis berita dengan menggunakan teknik ceramah oleh mahasiswa semester III program studi pendidikan bahasa dan sastra Indonesia FKIP UMSU tahun pembelajaran 2017-2018?

3. Untuk mengetahui pengaruh teknik pengelompokan (clustering) terhadap kemampuan menulis teks berita oleh mahasiswa semester III program studi pendidikan bahasa dan sastra Indonesia FKIP UMSU tahun pembelajaran 2017-2018?

\section{Pengertian Teknik Pengelompokan (clustering)}

Depdikbud (2007: 1158) menyatakan, “ Teknik adalah (1) pengetahuan dan kepandaian membuat sesuatu yang berkenaan dengan hasil industri, (2) cara membuat atau melestarikan atau meletakkan sesuatu yang berhubungan dengan seni, (3) metode atau sistem mengerjakan sesuatu.

Teknik adalah cara yang dapat dilakukan pendidikan agar mahasiswa dapat memahami sesuatu bahan kajian dalam suatu pembelajaran. Penentuan teknik pembelajaran dapat dipengaruhi oleh berbagai faktor. Faktor-faktor tersebut diantaranya sebagai: (1) tujuan, (2) materi, (3) pendekatan, (4) metode, (5) siswa (mahasiswa), (6) dan faktor situasi dan kondisi. Penggunaan suatu teknik pembelajaran yang berhasil dan efektif yang digunakan oleh seorang guru/dosen belum tentu sama hasilnya dengan guru/dosen lain yang menggunakan teknik pembelajaran yang sama dalam situasi dan kondisi yang lain. Oleh karena itu, guru/dosen perlu memiliki kemampuan dalam memilih dan menentukan teknik pembelajaran yang sesuai dengan faktor-faktor tersebut. 
Salah satu teknik pembelajaran yang dapat dipilih pendidikan (guru/mahasiswa) dalam pembelajaran yaitu teknik pengelompokan (clustering). Teknik ini dikembangkan oleh Gabriel Rico. Porter (2013:180), "Suatu cara memilih pemikiran-pemikiran yang saling berkaitan dengan menuangkannya di atas kertas secepatnya tanpa mempertimbangkan kebenaran atau nilainya." Artinya sebuah pemikiran yang dikelompokan diatas kertas hampir sama seperti proses berpikir yang terjadi didalam otak, walaupun dalam bentuk yang disederhanakan. Porter (2013:184) menambahkan bahwa pendidikan dapatmenggunakan teknik ini untuk segala jenis tulisan, dari mulai laporan, esai, proposal, sehingga tek beritadan cerita. Dengan kata lain, teknik pembelajaran pengelompokan ini sangatcocok untuk pembelajaran menulis teksberita. Berdasarkan penjelasan diatas dapat disimpulkan bahwa pengertian teknik pengelompakan (clustering) ini adalah suatu teknik pembelajaran yang berpusat pada siswa dengan cara mengelompokan kata ke dalam kertas dengan secepatnya untuk merangsang gagasan-gagasan pada pikiran siswa/mahasiswa dalam kegiatan menulis yang sebenarnya.

\section{Langkah-langkah Penggunaan Teknik Pembelajaran Clustering}

Teknik ini akan berhasil dengan baik apabila dilakukan dengan cara yang tepat. Tahapan-tahapan penggunaannya adalah sebagai berikut menurut Porter (2013:181):

1. Melihat dan membuat kaitan antara gagasan.

2. Mengembangkan gagasan-gagasan yang telah dikemukakan.

3. Menelusuri jalan pikiran yang ditempuh otak agar mencapai suatu konsep.

4. Bekerja secara alamiah dengan gagasan-gagasan tanpa menyuntingan atau pertimbangan.

5. Menvisualkan hal-hal khusus dan men, 4 nya kembali dengan mudah.

6. Mengalami desakan kuat untuk menulis.

Dari tahapan diatas, dapatlah diperjelas bahwa teknik pengelompokan ini terdiri atas beberapa langkah. Adapun pemaparan langkah-langkah tersebut adalah sebagai berikut:

1. Langkah pertama yaitu melihat dan membuat kaitan antara gagasan. Pada langkah ini guru/dosen memfasilitasi siswa/mahasiswa untuk menemukan kata yang berkaitan dengan pembelajaran, selanjutnya memberikan kesempatan kepada siswa/mahasiswa untuk menulis kata yang ditemukannya tersebut ke dalam kertas kosong, misalnya " langit" lalu melingkarinya, kemudian mahasiswa mencari lebih banyak lagi kata-kata yang berhubungan dengan kata "langit" tersebut, lalu mahasiswa menlingkari kata atau frase baru dan menghubungkannya.

2. Langkah kedua yaitu mengembangkan gagasan-gagasan yang telah dikemukakan. Pada langkah ini mahasiswa sudah menemukan kata yang saling berhubungan yang memicu suatu gagasan (pemikiran). Selanjutnya mahasiswa menuliskan hasil pemikirannya kedalam kertas tanpa pertimbangan apapun, walau hasil pemikiran yang ditulis tersebut tidak berhubungan atau tidak cocok.

3. Langkah ketiga yaitu menelusuri jalan pikiran yang ditempuh otak agar mencapai suatu konsep. Pada langkah ini dosen pembimbing mahasiswa untuk menelusuri jalan pikirannya terhadap apa yang telah dituliskannya tadi agar mahasiswa menyadari bahwa mereka mudah mempunyaikonsep untuk melakukan kegiatan menulis.

4. Langkah keempat yaitu bekerja secara alamiah dengan gagasan-gagasan tanpa penyuntingan atau pertimbangan. Pada langkah ini dosen membimbing mahasiswa untuk memposisikan setiap kata dalam tingkatan yang sama dengan gagasan lainnya dengan harapan mahasiswa dapat terus menghasilkan gagasan tanpa melakukan evaluasi terhadap gagasan tersebut.

5. Langkah kelima yaitu memvisualkan hal-hal khusus dan mengingatnya kembali dengan mudah. Selanjutnya pada langkah ini mahasiswa diminta untuk melihat kembali hasil pengelompokan untuk diberi nomor urut yang menurut mahasiswa logis untuk dijadikan bahan tulisan. Hasil pengelompokan tersebut merupakan landasan menulis yang dapat memunculkan gagasan lain. 
6. Langkag keenam yaitu mengalami desakan kuat untuk menulis. Pada langkah ini mahasiswa menulis pada tahapan sesungguhnya berlandaskan hasil pengelompokannya.

\section{3. .Pengertian Berita}

Secara bahasa berita berasal dari bahasa sansekerta, Vrit yang berarti ada atau terjadi. Kemudian dikembangkan kedalam kedalam bahasa Inggris menjadi, write yang berarti menulis. Sebagian orang menyebutnya, Vritta yang berarti kejadian atau yang terjadi. Lidah orang Indonesia menyebutnya berita. Dalam kamus besar bahasa Indonesia, berita diartikan sebagai, “laporan tercepat mengenai keiadian atau peristiwa yang hangat Cahya S. (2012:2).

Dengan demikian dapat disimpulkan bah. ${ }^{7}$ erita adalah suatu fakta atau ide atau opini aktual yang menarik dan akurat serta dianggap penting bagi sejumlah besar pembaca, pendengar maupun penonton atau melalui media massa umum.

\section{Teknik Menulis Berita}

Menulis berita tidak sama dengan menulis surat atau buku harian didalam kamar yang merupakan uneg-uneg hati. Menulis berita memerlukan kecakapan tersendiri dan harus memperhatikan ciri-ciri bahasa surat kabar dan jenis-jenis tulisan dalam surat kabar yang telah diungkapkan dimuka. Setiawan (2001:35).

Berikut ini beberapa hal yang harus diperhatikan dalam menulis berita:

1. Tulisan berita harus dapat menyentuh kebutuhaan manusia akan informasi, kesenangan, keinginantahuan, ketidakpahaman.

2. Berita yang ditulis di dalam surat kabar harus aktual sehingga tidak menjadi berita yang basi.

3. Penulisan berita untuk surat kabar harus cepatdan singkat tetapi kebenarannya dapat dipertanggungjawabkan dengan sumber yang jelas.

4. Tulisan berita harus dapat menjawab apa, kapan, siapa, bagaimana, dan dimana suatu berita yang ditulis, sehinga tidak membuat pembaca bertanya tentang ketidakjelasan berita.

5. Tulisan berita yang berkelanjutan tentang sesuatu hal, pada bagian akhir berita harus diungkapkan lagi tentang latar belakang peristiwa itu agar pembaca yang baru pembacanya (mengikutinya) menjadi jelas terhadap berita yang baru dibacanya itu.

\section{Struktur Berita}

Struktur berita merupakan susunan yang membentuk suatu berita. Struktur berita terdiri atas :

1. Judul berita (head line), merupakan identitas berita.

2. Titi mangsa ( data line), berkaitan dengan kapan berita itu dibuat.

3. Pembuka berita atas teras (lead) yaitu kalimat pembuka pada paragraf pertama yang memuat fakta atau informasi terpenting dari keseluruhan berita yang kita sampaikan.

4. Perangkat (bridge), adalah kata-kata penghubung antara teras berita dengan tubuh berita.

5. Tubuh (body), yaitu kalimat-kalimat, paragraf-paragraf yang merupakan kelanjutan dari teras berita.

6. Kaki berita (leg), yaitu bagian akhir dari penulisan berita.

\section{Unsur Berita}

Sebuah berita lazimnya mengandung 6 unsur yaitu berisi tentang pernyataan yang dapat menjawab $5 \mathrm{~W}+1 \mathrm{H}$. Penjelasan pada masing-masing unsur tersebut adalah:

1. What $($ apa $)=$ peristiwa apa yang terjadi.

2. When $($ kapan $)=$ waktu terjadinya peristiwa.

3. Where $($ dimana $)=$ tempat terjadinya peristiwa.

4. Who $($ siapa $)=$ siapa yang mengalami peristiwa

5. Why (mengapa) = mengapa peristiwa tersebut terjadi 
6. How (bagaimana) = bagaimana peristiwa tersebut terjadi

Unsur $5 \mathrm{~W}+1 \mathrm{H}$ dalam menulis berita mutlak diperlukan, sehingga tidak kekurangan informasi yang kita tulis Prayati Sudarman (2008:93).

\section{METODOLOGI PENELITIAN}

Penelitian ini direncanakan diadakan selama enam bulan, dimulai pada bulan Nopember 2017 sampai April 2018. Populasi dari penelitian iniadalah seluruh mahasiswa program studi Pendidikan Bahasa dan Sastra Indonesia semester III yang berjumlah 300, sedangkan sampel penelitian ini adalah dengan menggunakan random. Dua kertas yang terpilih akan menjadi kelas eksperimen dan kelas kontrol.

Tes digunakan untuk untuk mengetahui pengetahuan keterampilan siswa tentang menulis teks berita setelah mengikuti proses pembelajaran. Tes yang digunakan dalam penelitian ini adalah tes tertulis yang sesuai dengan materi. Dalam melakukan tes ini, diperlukan instrumen yang berupa pedoman atau kriteria penilaian. Penilaian tersebut menunjukan pencapaian aspek pokok yang dijadikan kreteria penilaian, yaitu : (1) kelengkapan unsur berita (mengandung ADIKSIMBA); (2) keruntutan pemaparan (isi urut dan jelas sehingga mudah dipahami); (3)penggunaan kalimat (singkat dan jelas); (4) penggunaan kosa kata (tepat); (5) kemanarikan judul; dan (6)ketepatan penggunaan ejaan dalam berita. Untuk menilai kemampuan mahasiswa dalam menulis teks berita, data memegang peranan penting. Untuk memperoleh data tersebut banyak cara yangditempuh, ada yang mengunakan tes, angket, wawancara, dan sebagainya sesuai dengan data yang dibutuhkan. Teknik pengumpulan data yang peneliti gunakan untuk mengetahui paruh yang signifikan pembelajaran teknik pengelompokan (clustering) terhadap kemampuan menulis teks berita adalah tes. Langkah yang ditempuh dalam melaksanakan percobaan adalah mengadakan tes tertulis yaitu essay test (esai tes). Tes esai yang diberikan kepada mahasiswa berupa instruksi yakni menugaskan mereka untuk menulis teks berita.

Selanjutnya untuk mengetahui kemampuan mahasiswa dalam menulis teks berita, peneliti akan menilai dan menginterpretasikan beberapa aspek yang dinilai. Aspek-aspek yang dinilai dapat dilihat pada tabel berikut. Aspek-aspek yang dinilai dapat dilihat pada tabel berikut. Aspek ini adalah aspek pilihan yang dianggap peneliti paling penting dalam menulis puisi di antara teksberita yang ada.

Dari skor yang diperoleh diubah dalam bentuk nilai akhir siswa dengan rumus sebagai berikut.

Jumlah nilai sepuluh aspek
Nilai rata-rata siswa $=$
Jumlah skor maksimal

Untuk mengetahui nilai rata-rata kelas dengan menggunakan penilaian rentang nilai maka penggunaan rumus berikut.

\begin{tabular}{|lc|}
\hline & Jumlah nilai seluruh siswa \\
Nilai rata- rata= & Jumlah siswa \\
\hline
\end{tabular}

Dari pedoman diatas, guru dapat mengetahui kemampuan menulis teks berita siswa berhasil mencapai kategori sangat baik, baik, cukup,kurang, dan sangat kurang. 


\section{HASIL PENELITIAN DAN PEMBAHASAN}

Kegiatan awal yang dilakukan peneliti sebelum melaksanakan tindakan dalam penelitian ini yaitu melakukan wawancara dengan guru bidang studi bahasa Indonesia kelas VIIIC SMP Negeri 8 Kendari khususnya pada kompetensi dasar menulis Berita.Berdasarkan data awal yang diperoleh dari hasil wawancara dengan guru bahasa Indonesia, pada semester satu untuk tahun pelajaran 2014/2015 pada kelas VIIIC SMP Negeri 8 Kendari dari 31 siswa hanya 7 orang siswa yang mencapai kriteria ketuntasan maksimal, Sedangkan 24 orang siswa lainnya tidak mencapai kriteria ketuntasan maksimal. Hasil observasi menunjukkan bahwa hasil belajar bahasa Indonesia siswa kelas VIIIC SMP Negeri 8 Kendari. Masih tergolong rendah serta metode pembelajaran yang digunakan guru metode ceramah dan mencatat. Berawal dari masalah tersebut, guru dan peneliti menyepakati untuk menerapkan model pembelajaran kontekstual dalam pembelajaran bahasa Indonesia di kelas VIII C pada materi ajar menulis teks Berita sebagai solusi untuk mengatasi permasalahan yangdihadapi.

Setelah ditetapkan untuk menerapkan model pembelajaran kontekstual pada kompetensi dasar menulis Teks Berita maka kegiatan selanjutnya adalah menyiapkan beberapa hal yang diperlukan pada saat pelaksanaan tindakan. Proses persiapan ini dilakukan dengan berkonsultasi antara peneliti sebagai guru pengajar. Setelah berkonsultasi dengan Dosen , peneliti melakukan hal-hal sebagai berikut.

1. Membuat skenario pembelajaran berupa Rencana Pelaksanaan Pembelajaran (RPP) untuk tindakan siklus I yang meliputi pertemuan ke-1 dan pertemuanke-2.

2. Peneliti danDosenbersama - sama merumuskan indikator pencapaian tujuan dan membuat observasi terhadap siswa dan Dosen selama proses pembelajaranberlangsung.

3. Dosen dan peneliti menyimpan lembar penilaian siswa berupa instrumen penelitian berupa soalkuis.

4. Dosen menyimpan lembar penelitian didasarkan aspek- aspek penilaian Teks Berita, yakni aspek (a) Kesesuaian judul dengan isi:(b) Koherensi antar kalimat(c)pilihan kata:(d)keefektifankalimat.

5. Dosen dan peneliti menentukan waktu dan jadwal pelaksanaan siklus pertama berdasarkan pertimbangan jadwal pelajaran bahasa Indonesia Akhirnya disepakati penelitia 


\section{Hasil Observasi Aktivitas Mahasiswa}

Pengamatan terhadap aktivitas belajar mahasiswa juga dilakukan bersamaan dengan pemberian tindakan pada siklus I. Observasi dimulai dari kegiatan awal sampai pada kegiatan akhir.Observasi pada proses pembelajaran dapat dilihat pada tabel berikut.

Tabel 1. Observasi Aktivitas Mahasiswaa Selama Kegiatan Pembelajaran Berlangsung paada Siklus I

\begin{tabular}{|c|c|c|c|}
\hline No & Aspek - aspek yang diamati & B & $\mathbf{K}$ \\
\hline 1. & Mahasiswa terlibat dalam proses belajar mengajar. & $\sqrt{ }$ & \\
\hline 2. & $\begin{array}{l}\text { Mahasiswa kurang memberikann respon yang baik } \\
\text { karena siswa yang duduk dideretan belakang sibuk } \\
\text { mengatur } \\
\text { tempat duduknya. }\end{array}$ & & V \\
\hline 3. & $\begin{array}{l}\text { Ketika disuruh bertanya, tidak ada Mahasiswa yang } \\
\text { berani } \\
\text { bertanya. }\end{array}$ & & V \\
\hline 4. & Mahasiswa mampu menggunakan otak berpikirnya. & & $\sqrt{ }$ \\
\hline 5. & $\begin{array}{l}\text { Teks berita model kontekstual mulai menarik perhatian } \\
\text { Mahasiswa dan Mahasiswa bertanya terkait materi. }\end{array}$ & & $\sqrt{ }$ \\
\hline 6. & Mahasiswa bertanya jawab dengan dosen & $\sqrt{ }$ & \\
\hline & Mahasiswa menyimak penjelasan doen. & $\sqrt{ }$ & \\
\hline 8. & $\begin{array}{l}\text { Mahasiswa mulai tenang dan berpikir serta mengingat } \\
\text { kembali pengalaman dan pengetahuan yang sudah } \\
\text { didapat baik diluar maupun didalam sekolah. }\end{array}$ & $\sqrt{ }$ & \\
\hline 9. & $\begin{array}{l}\text { Mahasiswa mulai tenang ketika mendapat teguran dari } \\
\text { dosen. }\end{array}$ & $\sqrt{ }$ & \\
\hline 10. & $\begin{array}{l}\text { Ketua kelas mengarahkan teman - temannya agar tidak } \\
\text { ribut sehingga pelajaran berjalan lancar. }\end{array}$ & $\sqrt{ }$ & \\
\hline 11. & Siswa sadar apapun yang dilakukan dtidak sia - sia. & $\sqrt{ }$ & \\
\hline \multicolumn{2}{|c|}{ Jumlah Skor } & 7 & 4 \\
\hline \multicolumn{2}{|c|}{ Rata - rata } & 63 & 36 \\
\hline
\end{tabular}

B: Baik

K: Kurang Baik

Berdasarkan tabel tersebut, diperoleh data kegiatan belajar mengajar yang dilakukan oleh siswa yaitu:

\section{a. KegiatanMahasiswa}

1. Pada kegiatan awal mahasiswa kurang terlibat dalam proses belajar karena sebagian mahasiswa masih berada diluarkelas.

2. Mahasiswa kurang memberikan respon yang baik karena mahasiswa yang duduk dideretan belakang sibuk mengatur tempatduduknya.

3. Ketika disuruh bertanya, mahasiswa tidak ada yang beranibertanya. 
4. Mahasiswa mampu menggunakan otakberpikirnya.

5. Teks berita mulai menarik perhatian siswa dan bertanya terus terkaitpembelajaran.

6. Mahasiswabertanya

7. Mahasiswa menyimak penjelasandosen.

8. Mahasiswa mulai tenang dan berpikir serta mengingat - ingat berdasarkan pengalaman dan pengetahuan yang sudah didapatkan baik diluar maupun didalamsekolah.

9. Mahasiswa mulai tenang ketika mendapat teguran daridosen.

10. Ketua kelas mengarahkan teman - temannyaagartidak ribut sehingg apelajaran berjalan lancar.

11. Mahasiswa sadar apapun yang dilakukan tidak sia -sia.

\section{b. Evaluasi}

Kegiatan evaluasi siklus dilakukan secara individual .Adapun data hasil tes kemampuan siswa yakni setiap siswa menyelesaikan soal sendiri.

Soal evaluasi silklus I dapat dilihat pada lampiran penelitian ini.Adapun data hasil tes kemampuan mahasiswa semester III kelas A Pagi dalam menulis teks berita adalah sebagai berikut.

Tabel 2. Hasil Evaluasi belajar Siklus I

\begin{tabular}{|c|c|c|c|}
\hline No & Nilai & Keberhasilan & Keterangan \\
\hline 1 & 53 & $53 \%$ & Tidak Tuntas \\
\hline 2 & 66 & $66 \%$ & Tidak Tuntas \\
\hline 3 & 53 & $53 \%$ & Tidak Tuntas \\
\hline 4 & 75 & $75 \%$ & Tuntas \\
\hline 5 & 66 & $66 \%$ & Tidak Tuntas \\
\hline 6 & 74 & $74 \%$ & Tuntas \\
\hline 7 & 80 & $80 \%$ & Tuntas \\
\hline 8 & 88 & $88 \%$ & Tuntas \\
\hline 9 & 60 & $60 \%$ & Tidak Tuntas \\
\hline 10 & 62 & $62 \%$ & Tidak Tuntas \\
\hline 11 & 41 & $41 \%$ & Tidak Tuntas \\
\hline 12 & 62 & $62 \%$ & Tidak Tuntas \\
\hline 13 & 70 & $70 \%$ & Tuntas \\
\hline 14 & 53 & $53 \%$ & Tidak Tuntas \\
\hline 15 & 60 & $60 \%$ & Tidak Tuntas \\
\hline 16 & 35 & $35 \%$ & Tidak Tuntas \\
\hline 17 & 40 & $40 \%$ & Tidak Tuntas \\
\hline 18 & 66 & $66 \%$ & Tidak Tuntas \\
\hline 19 & 55 & $55 \%$ & Tidak Tuntas \\
\hline 20 & 60 & $60 \%$ & Tidak Tuntas \\
\hline 21 & 74 & $74 \%$ & Tuntas \\
\hline 22 & 59 & $59 \%$ & Tidak Tuntas \\
\hline 23 & 55 & $55 \%$ & Tidak Tuntas \\
\hline
\end{tabular}




\begin{tabular}{|l|l|l|l|}
\hline 24 & 66 & $66 \%$ & Tidak Tuntas \\
\hline 25 & 70 & $70 \%$ & Tuntas \\
\hline 26 & 90 & $90 \%$ & Tuntas \\
\hline 27 & 77 & $77 \%$ & Tuntas \\
\hline 28 & 41 & $41 \%$ & Tidak Tuntas \\
\hline 29 & 85 & $85 \%$ & Tuntas \\
\hline 30 & 75 & $75 \%$ & Tuntas \\
\hline 31 & 60 & $60 \%$ & Tidak Tuntas \\
\hline $\begin{array}{l}\text { Jumlah } \\
\text { Mahasiswa } \\
\text { Tuntas }\end{array}$ & 11 & \\
\hline $\begin{array}{l}\text { Jumlah } \\
\text { Mahasiswa } \\
\text { tidak tuntas }\end{array}$ & 20 & \\
\hline
\end{tabular}

Tabel 3. Analisis Ketuntasan Hasil Belajar Mahasiswa siklus I

\begin{tabular}{|c|c|c|c|}
\hline No & Nilai (x) & Frekuensi(x) & \\
\hline 1. & 95 & 1 & 95 \\
\hline 2. & 90 & 1 & 90 \\
\hline 3. & 73 & 1 & 73 \\
\hline 4. & 71 & 1 & 71 \\
\hline 5. & 75 & 2 & 150 \\
\hline 6. & 77 & 1 & 77 \\
\hline 7. & 74 & 2 & 148 \\
\hline 8. & 70 & 2 & 140 \\
\hline 9. & 62 & 2 & 124 \\
\hline 10. & 55 & 2 & 110 \\
\hline 11. & 59 & 1 & 59 \\
\hline 12 & 53 & 3 & 59 \\
\hline 13 & 60 & 4 & 240 \\
\hline 14 & 35 & 1 & 35 \\
\hline 15 & 40 & 1 & 40 \\
\hline 16 & 41 & 2 & 82 \\
\hline 17 & 66 & 4 & 264 \\
\hline & Jumlah & 31 & 1957 \\
\hline \multicolumn{3}{|c|}{ Rata- rata } & 63,12 \\
\hline
\end{tabular}


Berdasarkan pengamatan dari segi hasil secara klasikal dapat dikemukakan bahwa hasil tes kemampuan menulis teks berita mahasiswa kelas A pagi pada siklus I belum mencapai indikator kinerja yang ditetapkan yakni 35\% (20) yang memperoleh nilai $\leq 70$, dengan nilai rata-rata 63,12 .

\section{c. Analisis}

Kelemahan pada siklus I

1. Pada saat membuka perkuliahan dosen tidak mengucapkan salam.

2. Dalam menginformasikan materi dosen juga harus memperhatikan mahasiswa yang duduk dibangkubelakang.

3. Dosen kurang dalam menyampaikan tujuan pelajaran karena hanya menyampaikan secara umum.

4. Dosen masih kurang dalam menjelaskan materi pembelajaran.

5. Dosen masih kurang dalam memerintahkan siswa untuk melakukan perbaikan terhadap tulisannya.

6. Dosen kurang memotivasi siswa, sehingga hal ini berdampak pada suasana kelas yaitu siswa kurang bersemangat mengikutipelajaran.

7. Dosen masih relatif kurang memberikan arahan dan bimbingan kepada siswa pada saat pembelajaranberlangsung.

8. Dosen belum mampu mengelola waktu pembelajaran denganbaik.

9. Dosen tidak melakukan refleksi.

\section{d. Refleksi}

Pada tahapan ini dosen dan peneliti berkolaborasi, mendiskusikan beberapa hal yang perlu dijadikan refleksi untuk perbaikan pada siklus berikutnya. Beberapa hal tersebut antara lain:

\section{DAFTAR PUSTAKA}

Ahmadi, M. 1988. Materi Dasar Pengajaran Komposisi Bahasa Indonesia. Jakarta: Depdikbud.

Akhadiah, S., Maidar, G.A., dan Sakura, H.R. 1989. Pembinaan Kemampuan Menulis Bahasa Indonesia. Jakarta: Erlangga.

Haryadi dan Zamzami. 1996. Peningkatan Keterampilan Berbahasa Indonesia. Jakarta: Depdikbud Dikti

Kosasih, E. 2002. Kompetensi Ketatabahasaan: Cermat Berbahasa Indonesia. Bandung: Yrama Widya.

Gie, The Liang. 2002. Terampil Mengarang. Yogyakarta. ANDI.

Raimes. Ann._. Ten Step in Planning a Writing Course and Training Teacher of Writing. Artikel.

Reppen, Randi. A Genre-Based Approach to Content Writing Instruction. Artikel.

Seow, Anthony. The Writing Process and Process Writing. Artikel.

Barus, Sedia Willing. 2011. Jurnalistik: Petunjuk Teknis Menulis Berita.

Jakarta: Erlangga.

Syamsul M. Romli, Asep. “Teknik Menulis Berita”. 2 April 2017

http://jurnalistikpraktis.blogspot.co.id/

Tea, Romel. "Jenis-Jenis Berita Jurnalistik”. 2 April 2017

http://www.romelteamedia.com 